Volume 68

Issue 3 Spring 2019

Article 5

\title{
Chevron's Political Domain: W(h)ither Step Three
}

Justin (Gus) Hurwitz

Follow this and additional works at: https://via.library.depaul.edu/law-review

Part of the Law Commons

\section{Recommended Citation}

Justin (Gus) Hurwitz, Chevron's Political Domain: W(h)ither Step Three, 68 DePaul L. Rev. (2019)

Available at: https://via.library.depaul.edu/law-review/vol68/iss3/5

This Essay is brought to you for free and open access by the College of Law at Digital Commons@DePaul. It has been accepted for inclusion in DePaul Law Review by an authorized editor of Digital Commons@DePaul. For more information, please contact digitalservices@depaul.edu. 


\title{
CHEVRON'S POLITICAL DOMAIN: W(H)ITHER STEP THREE?
}

\author{
Justin (Gus) Hurwitz*
}

\section{Contents}

INTRODUCTION ................................... 616

I. Chevron \& Politicization: The Debate ........... 621

II. The Measure of Politicization ................. 624

III. The Institutional Design of Politicization ....... 627

IV. Politicization and the Deference Domain ....... 629

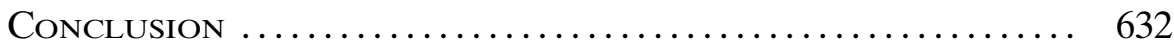

This Essay takes prior work on Chevron in a new direction, arguing that broad deference doctrines have the largely unrecognized but particularly pernicious effect of increasing the political gridlock and politicization of the legislative process. Untethered from the need to actively govern agencies that have been delegated sufficiently broad authority to keep the basic ship of state afloat, legislators refocus their attention on maintaining power for themselves and their political party. In the thirty or so years since Chevron became the law of the land, our country's governing institutions have grown increasingly politicized: At the risk of overstating this Essay's claim, perhaps Chevron itself-and the related embrace of broad judicial deference to the administrative state of which it is part-is in some measure responsible for our current sorry political state.

This is an undesirable outcome. And, as framed here, it is not only unfortunate, but also problematic on separation of powers grounds. The intuition explored in this Essay is that Chevron dramatically exacerbates Congress's worst tendencies, encouraging Congress to push its constitutional legislative duties to the Executive. Chevron thus

* Associate Professor of Law and Co-Director, Space, Cyber, and Telecom Law Program, University of Nebraska College of Law and Director of Law \& Economics Programs, International Center for Law \& Economics; Program Affiliate NYU School of Law Classical Liberalism Institute. JD, University of Chicago, 2007; MA, George Mason University (economics), 2010; BA, St. John's College, 2003. An earlier version of this piece appeared on the International Center for Law \& Economics's Truth on The Market Blog. Thanks to Chris Walker, Aaron Neilson, Adam White, Geoff Manne, and Kristian Stout for helpful feedback on this piece, and to Jackson Slechta for research assistance. 
effectively allows, and indeed encourages, Congress to abdicate its role as the most politically-accountable branch by deferring politically difficult questions to agencies. This argument is, at core, based in separation of powers concerns. While separation of powers concerns generally focus on preventing one branch of government from encroaching into the realm of the other branches, this Essay offers a twist, arguing that Chevron's demurral to agency interpretations encourages a Congressional abdication of its constitutional responsibilities-and that such deference is therefore an abdication of the Judiciary's constitutional role as a check on the problematic conduct of its sister branches.

\section{INTRODUCTION}

When a federal agency ${ }^{1}$ misconstrues or misuses the authority delegated to it by Congress, Congress can correct that agency's action through legislation. Courts may also be able to correct that agency's action. In some cases, courts may decide that the action clearly is not permissible under the agency's authorizing statute. In other cases, courts may decide that the meaning of that statute is ambiguous and the agency's interpretation is sufficiently permissible, so they may allow the agency's action. In either event, if Congress disagrees with the court's review of the agency's action, Congress can correct the agency's action, and the court's treatment of it, through legislation.

In the context of judicial review, we can situate this in the familiar Chevron dynamic. ${ }^{2}$ At Step One, a court asks whether a statute is ambiguous. If it is, then at Step Two the court asks whether the agency's construction of that statute is a permissible interpretation of it. Then, at Step Three, Congress corrects the court's or the agency's interpretation of that statute through legislation.

Of course, there is no Chevron Step Three. But while Congress may legislatively address any concerns that it has about how either agencies or the courts interpret the legislation that it enacts, the argument of this Essay is that Chevron-and, more generally, the principles of judicial deference to agencies that the Chevron doctrine embodiesactually makes such legislative action less likely than it would be in a world without so deferential a doctrine. In other words, not only is

1. This Essay uses "agency" to refer to both executive and independent agencies, and sometimes also to the "Executive" as referring both to the President but also to agencies exercising executive authority in carrying out legislative commands. The concerns expressed in this Essay apply in similar kind to both independent and executive agencies.

2. Chevron, U.S.A., Inc. v. Nat. Res. Def. Council, Inc., 467 U.S. 837, 842-43 (1984). This Essay is intended for an audience familiar with the Chevron doctrine, so it foregoes with doctrinal background beyond what is relevant to the discussion. 
there formally no Step Three to the Chevron doctrine, but the Chevron doctrine itself encourages Congress to give expansive deference to agencies and makes it less likely that Congress will exercise its constitutional control over the execution of the laws that it enacts.

That alone may be concerning on formalistic grounds. The idea that judicial deference to agency interpretations of ambiguous statutes actually induces ambiguous statutory drafting by Congress is a compelling hypothesis on its own-one that has been studied at some length. ${ }^{3}$ Scholars considering this question, for instance, have considered how the existence of deference affects the way Congress drafts statutes and how deference to either institution (i.e., agencies or courts) affects the incentives of individual legislators as a function of how close their preferred legislative outcomes are to those of the median legislator. ${ }^{4}$ And, of particular relevance to this Essay, scholars have also considered how the existence of deference doctrines affects the balance of legislative efforts to police how agencies use their legislative authority (e.g., through oversight hearings) versus relying on litigation outcomes to signal problematic use of authority by agencies. ${ }^{5}$

This Essay takes this prior work in a new direction, arguing that broad deference doctrines ${ }^{6}$ have an additional, particularly pernicious, effect of increasing the politicization of the legislative process. Not only do Chevron and related deference doctrines affect how legislators go about the business of Congress, but they change legislators' understanding of what the business of Congress is. Untethered from the need to actively govern agencies that have been delegated sufficiently broad authority to keep the basic ship of state afloat, legislators myopically refocus their attention on maintaining power for themselves and their political party. In this light, and at the risk of overstating this Essay's claim, in the thirty or so years since Chevron became the law of the land, our country's governing institutions have grown increasingly politicized: Perhaps Chevron itself, and the related embrace of broad judicial deference to the administrative state of which it is part, is in some measure responsible for this sorry political state.

3. See, e.g., Lisa Schultz Bressman, Chevron's Mistake, 58 Duke L.J. 550, 571 (2009).

4. Id. at 566-71.

5. Id. at 570; see also Mathew D. McCubbins \& Thomas Schwartz, Congressional Oversight Overlooked: Police Patrols Versus Fire Alarms, 28 Aм. J. PoL. ScI. 165, 166 (1984).

6. This Essay is framed in terms of Chevron, but the discussion reflects upon "deference doctrines" more generally. The term "deference doctrines" is used throughout, with specific reference to Chevron as such a doctrine, but reflecting broader concerns about overbroad judicial deference to agency decisions. The final portion of this Essay expands the discussion to situate these concerns more generally. See sources cited infra note 58. 
This is an undesirable outcome. And, as framed here, it is not only unfortunate but also problematic on separation of powers grounds. ${ }^{7}$ Conversely stated, if this Essay's argument holds some truth, separation of powers principles may offer some remedy to combat the harms that Chevron has caused to our constitutional republic.

The intuition explored in this Essay is that Chevron dramatically exacerbates Congress's worst tendencies, encouraging Congress to push its legislative functions to the Executive and to do so in a way that increases the politicization and polarization of American law and policy. This gives rise to a fear that Chevron effectively allows, and indeed encourages, Congress to abdicate its role as the most politically-accountable branch by deferring politically-difficult questions to agencies in ambiguous terms. This argument is, at core, based in separation of powers concerns. While separation of powers concerns generally focus on preventing one branch of government from encroaching into the realm of the other branches, this Essay offers a twist, arguing that Chevron's demurral to agency interpretations encourages a Congressional abdication of its constitutional responsibilities-and that such deference is therefore an abdication of the Judiciary's constitutional role as a check on the problematic conduct of its sister branches.

This discussion is situated in the context of several contemporary debates. The ongoing vitality of the Chevron doctrine has been in question for several years in the academic literature, ${ }^{8}$ and more recently by a growing chorus on the Supreme Court. ${ }^{9}$ The legitimacy of

7. This Essay is of a feather with concerns expressed by others about the deterioration of the separation of powers and the effects of that deterioration on the relationship between the Legislative and Executive branches. See, e.g., Brett M. Kavanaugh, Separation of Powers During the Forty-Fourth Presidency and Beyond, 93 Minn. L. Rev. 1454, 1455 (2009) ("Many of those broken structures and systems [in Washington, D.C.] implicate the separation of powers-and particularly, the interaction of the legislative and executive branches in performing their respective and sometimes overlapping functions under the Constitution.").

8. See, e.g., Philip Hamburger, Chevron Bias, 84 Geo. WASH. L. Rev. 1187 (2016) [hereinafter Hamburger, Chevron Bias]; Michael Herz, Chevron is Dead; Long Live Chevron, 115 Colum. L. REv. 1867 (2015); Jonathan R. Siegel, The Constitutional Case for Chevron Deference, 71 VAND. L. REv. 937 (2018). See generally Peter M. Shane \& Christopher J. Walker, Chevron at 30: Looking Back and Looking Forward, 83 ForD. L. REv 475 (2014). Discussions about Chevron fit more generally into, and are a specific locus of concern within, ongoing discussions about the legitimacy of the administrative state. As noted by Bill Funk, "More recently, however, there has been a concerted effort arising in the academy, Congress, and the courts to undermine agency regulation as fundamentally illegitimate-if not unconstitutional." William Funk, The Attack on Administrative Regulation, 42 VT. L. REv. 427, 427-28 (2018).

9. See, e.g., Pereira v. Sessions, 138 S. Ct. 2105, 2120 (2018) (Kennedy, J., concurring); SAS Inst., Inc. v. Iancu, 138 S. Ct. 1348, 1358 (2018); see also Michigan v. EPA, 135 S. Ct. 2699, 2712 (2015) (Thomas, J., concurring) (noting "serious questions about the constitutionality of our broader practice of deferring to agency interpretations of federal statutes" under Chevron); Gu- 
the administrative state has been a central debate since we have had an administrative state-and again has been of particular interest in recent years. ${ }^{10}$ The politicization of the Judiciary, again of longstanding importance, has crescendoed with recent nominations of Supreme Court Justices. ${ }^{11}$ And, more narrowly, especially following the nomination of Brett Kavanaugh to the Supreme Court, questions about the Major Questions Doctrine-an exception or limitation to the usual application of Chevron that has only occasionally, but with increased frequency in recent years, been invoked by the Court ${ }^{12}$

tierrez-Brizuela v. Lynch, 834 F.3d 1142, 1154, 1158 (10th Cir. 2016) (in which then-Judge Gorsuch wrote a concurrence to his own majority opinion, writing that "Not only is Chevron's purpose seemingly at odds with the separation of legislative and executive functions, its effect appears to be as well .... We managed to live with the administrative state before Chevron. We could do it again."); Kent Barnett, Christina L. Boyd, \& Christopher J. Walker, Judge Kavanaugh, Chevron Deference, and the Supreme Court, Regulatory Rev. (Sept. 3, 2018), https:// www.theregreview.org/2018/09/03/barnett-boyd-walker-kavanaugh-chevron-deference-supremecourt/.

10. See generally Philip Hamburger, Is Administrative Law Unlawful? (2015) [hereinafter Hamburger, Is Administrative Law Unlawful?].

11. Elliott Ash \& Daniel L. Chen, Kavanaugh Is Radically Conservative. Here's the Data to Prove It., WAsh. Post (July 10, 2018), https://www.washingtonpost.com/news/posteverything/wp/ 2018/07/10/kavanaugh-is-radically-conservative-heres-the-data-to-prove-it/; Robert Barnes \& Ed O'Keefe, Supreme Court Nominee Gorsuch Stresses His Independence from President Trump, WAsh. Post (Mar. 21, 2017), https://www.washingtonpost.com/powerpost/supreme-court-nomi nee-gorsuch-starts-day-two-of-confirmation-hearings/2017/03/20/ccd81b02-0dbf-11e7-9d5a-a83e6 27dc120_story.html; Clare Foran \& Joan Biskupic, Where Brett Kavanaugh Stands on Key Issues, CNN (Oct. 6, 2018, 4:24 PM), https://www.cnn.com/2018/07/09/politics/kavanaugh-on-the-issues/ index.html; Matthew Goldstein, Brett Kavanaugh Likely to Bring Pro-Business Views to Supreme Court, N.Y. Times (July 10, 2018), https://www.nytimes.com/2018/07/10/business/kava naugh-supreme-court-business-regulation.html; Carl Hulse, Gorsuch, Like Previous Supreme Court Nominees, Keeps Views Hidden, N.Y. Times (Feb. 20, 2017), https://www.nytimes.com/ 2017/02/20/us/politics/gorsuch-like-previous-supreme-court-nominees-keeps-views-hidden.html; Ariane de Vogue, Neil Gorsuch on the Issues, CNN (Mar. 20, 2017, 7:11 AM), https://www.cnn .com/2017/03/20/politics/neil-gorsuch-abortion-religious-liberty-environment-gun-control/index .html.

12. The "Major Questions Doctrine" (which Justice Kavanaugh has referred to as the Major Rules Doctrine) is a limitation on the Chevron doctrine that courts sometimes apply to limit the discretion of agencies to interpret statutes in ways that implicate "question[s] of deep 'economic and political significance.'” See King v. Burwell, 135 S. Ct. 2480, 2489 (quoting FDA v. Brown \& Williamson Tobacco Corp., 529 U.S. 120, 160 (2000)). The Chevron doctrine is premised in part on an assumption that Congress intentionally leaves ambiguities in statutes, such that ambiguity constitutes an implied delegation to agencies to resolve that ambiguity. The Major Questions Doctrine is similarly premised on an assumption that Congress would not silently delegate such authority to agencies over questions of "deep economic and political significance," such that Chevron deference should not extend to such matters. The Supreme Court has only occasionally invoked this concept-although in recent years, the Supreme Court and the D.C. Circuit, with then-Judge Kavanaugh, have turned to it with increased frequency. See generally Major Question Objections, 129 Harv. L. Rev. 2191 (2016); Michael Sebring, The Major Rules Doctrine: How Justice Brett Kavanaugh's Novel Doctrine Can Bridge the Gap Between the Chevron and Nondelegation Doctrines, 12 N.Y.U. J.L. \& LiBR. 189 (2018). 
are receiving more attention. ${ }^{13}$

This Essay is prompted, in particular, by a recent exchange between Chris Walker ${ }^{14}$ and Philip Hamburger ${ }^{15}$ about Walker's ongoing empirical work on the Chevron doctrine. ${ }^{16}$ In the interest of being provocative, I frame the discussion below by saying that both Walker and Hamburger are wrong-or, more accurately, both are quite correct in their respective critiques but neither critique confronts the central questions of how Chevron affects the politicization of decision-making. In particular, I argue that Walker is wrong about Chevron decreasing politicization (it actually increases it, vice his empirics); and I argue Hamburger is wrong about judicial independence being, on its own, a virtue that demands preservation. Rather, I argue, Chevron increases overall politicization across the government; and judicial independence can and should play an important role in checking legislative abdication of Congress's role as a politically-accountable branch in a way that would moderate that overall politicization.

One, and possibly the best, way to remedy this situation is to reestablish the role of judge as independent decision maker, as Hamburger argues. But, contra Hamburger, the virtue of judicial independence is not endogenous to the Judiciary. Rather, judicial independence has an instrumental virtue, at least in the context of Chevron. Where Congress has problematically abdicated its role as a politically-accounta-

13. See generally Daniel Deacon, Judge Kavanaugh and "Weaponized Administrative Law", YAle J. On Reg.: Notice \& COMment (July 11, 2018), http://yalejreg.com/nc/judge-kavanaughand-weaponized-administrative-law-by-daniel-deacon/; Tejas N. Narechania (@tnarecha), TwITTER (July 11, 2018, 3:49 PM), https://twitter.com/tnarecha/status/1017179030645161984; Jeffrey Pojanowski, Cabining the Chevron Doctrine the Kavanaugh Way, L. \& LiberTy (June 12, 2017), http://www.libertylawsite.org/2017/06/12/cabining-the-chevron-doctrine-the-kavanaugh-way/.

14. Christopher J. Walker, The Federalist Society's Chevron Deference Dilemma, L. \& LiBERTY (Apr. 3, 2018), https://www.lawliberty.org/2018/04/03/the-federalist-societys-chevron-defer ence-dilemma/ [hereinafter Walker, Deference Dilemma].

15. Philip Hamburger, Chevron Bias, Illustrated by Statistics, L. \& LiBerTy (Apr. 12, 2018), http://www.libertylawsite.org/2018/04/12/chevron-deference-administrative-state-philip-hamburg er/ [Hamburger, Chevron Bias, Illustrated by Statistics].

16. Walker, along with co-authors Kent Barnett and Christina Boyd, has done some of the most important and interesting work on Chevron in recent years, empirically studying how the Chevron doctrine has affected judicial behavior as well as that of agencies (and, I would argue, through them the Executive). For a discussion of the effect of Chevron on judicial behavior, see Kent Barnett \& Christopher J. Walker, Chevron in the Circuit Courts, 116 Mich. L. Rev. 1 (2017); Kent H. Barnett, Christina L. Boyd, \& Christopher J. Walker, Administrative Law's Political Dynamics, 71 VAND. L. Rev. 1463 (2018). For a discussion of the effect of Chevron on agency behavior, see Christopher J. Walker, Inside Agency Statutory Interpretation, 67 STAN. L. REv. 999 (2015). But the even more important question, in my mind and which Walker has only briefly touched on, is how it affects the behavior of Congress. See generally Christopher J. Walker, Legislating in the Shadows, 165 U. PA. L. REv. 1377 (2017) (discussing how the role agencies play in the legislative process implicitly transfers Congress's legislative functions to the Executive). 
ble decision maker by deferring important political decisions to the Executive, judicial refusal to defer to executive and agency interpretations of ambiguous statutes can force Congress to remedy problematic ambiguities. This, in turn, can return the responsibility for making politically-important decisions to the most politically-accountable branch, as envisioned by the Constitution's framers. ${ }^{17}$

This Essay proceeds in four Parts: a brief overview of the Chevron debate, framed in terms of the dialogue between Walker and Hamburger; a brief critique of Walker's assertion that Chevron has reduced the politicization of the Judiciary, arguing that politicization of the Judiciary is not a particularly useful metric of politicization; a discussion of how comparative institutional designs of judicial review and legislative process affect the politicization of that process; and, finally, a discussion of how different approaches to judicial deference affect the politicization of the legislative process within any given legislative institutional design.

\section{Chevron \& Politicization: The Debate}

Chevron is one of the defining doctrines of administrative law, both as a central concept and focal debate. It stands generally for the proposition that when Congress gives agencies ambiguous statutory instructions, it falls to the agencies, not the courts, to resolve those ambiguities. Thus, if a statute is ambiguous (the question at Step One of the standard Chevron analysis) and the agency offers a reasonable interpretation of that ambiguity (Step Two), courts are to defer to the agency's interpretation of the statute instead of supplying their own.

This judicially-crafted doctrine of deference is typically justified on several grounds. For instance, agencies generally have greater subjectmatter expertise than courts, so they are more likely to offer substantively better constructions of ambiguous statutes. Agencies have more resources that they can dedicate to evaluating alternative constructions. They generally have a longer history of implementing relevant Congressional instructions, so they are more likely attuned to Congressional intent-both of the statute's enacting and present Congresses. And they are subject to more direct Congressional oversight in their day-to-day operations and exercise of statutory authority than

17. The Federalist No. 57 (Alexander Hamilton); see also The Federalist No. 78 (Alexander Hamilton) ("[A] voluminous code of laws is one of the inconveniences necessarily connected with the advantages of a free government. To avoid an arbitrary discretion in the courts, it is indispensable that they should be bound down by strict rules and precedents, which serve to define and point out their duty in every particular case that comes before them ...."). 
the courts, so they are more likely concerned with and responsive to Congressional direction.

Chief among the justifications for Chevron deference is, as Walker says, "the need to reserve political (or policy) judgments for the more politically accountable agencies ...." 18 This is at core a separation-ofpowers justification: The legislative process is fundamentally a political process, so the Constitution assigns responsibility for it to the most politically-accountable branch (the Legislature) instead of the least politically-accountable branch (the Judiciary). In turn, the act of interpreting statutory ambiguity is an inherently legislative process-the underlying theory being that Congress intended to leave such ambiguity in the statute in order to empower the agency to interpret it in a quasi-legislative manner. Thus, under this view, courts should defer to this Congressional intent that the agency be empowered to interpret its statute (and, should this prove problematic, it is up to Congress to change the statute or to face political ramifications). Courts should also defer to the agency interpretation of that statute because agencies, like Congress, are more politically accountable than the courts.

Chevron has always been an intensively studied and debated doctrine. This debate has grown more heated in recent years, to the point that there is ongoing scholarly discussion about whether Chevron should be repealed or narrowed and what would replace it if it were somehow curtailed. ${ }^{19}$ And discussion of the ongoing vitality of Chevron has entered into Supreme Court opinions and the appointments process with increasing frequency. ${ }^{20}$ These debates generally focus on a few issues. A first issue is that Chevron amounts to a transfer of the Legislature's constitutional powers and responsibilities over creating the law to the Executive, where the law ordinarily is only meant to be carried out. This has, the underlying concern is, contributed to the increase in the power of the Executive compared to that of the Legislature. A second, related issue is that Chevron contributes to the (over)empowerment of independent agencies. These agencies are already out of favor with many of Chevron's critics as constitutionallyinfirm entities whose already-specious power is dramatically increased when Chevron limits the Judiciary's ability to check their use of already-broad Congressionally-delegated authority.

18. Walker, Deference Dilemma, supra note 14; see also Chevron, U.S.A., Inc. v. Nat. Res. Def. Council, Inc., 467 U.S. 837, 865 (1984) ("Judges are not experts in the field, and are not part of either political branch of the Government.").

19. See sources cited supra note 8 .

20. See sources cited supra note 9 . 
A third concern about Chevron, following on these first two, is that it strips the Judiciary of its role as independent arbiter of judicial questions. That is, it has historically been the purview of judges to answer statutory ambiguities and fill in legislative interstices.

Chevron is also a focal point for more generalized concerns about the power of the modern administrative state. In this context, Chevron stands as a representative of a broader class of cases-State Farm, ${ }^{21}$ Auer and Seminole Rock, ${ }^{22}$ City of Arlington, ${ }^{23}$ Brand- $X,{ }^{24}$ Fox $v$. $F C C, 25$ and the like-all of which are, at core, about the extent to which courts should defer to agencies and all of which have tended to support incrementally more deference. Thus Chevron allows Congress to abdicate its role as politically-accountable legislator, abdicates the Judiciary's role in interpreting the law, and raises due process concerns for those subject to rules promulgated by federal agencies.

Walker and his co-authors have empirically explored the effects of Chevron in recent years, using robust surveys of federal agencies and judicial decisions to understand how the doctrine has affected the work of agencies and the courts. His most recent work (with Kent Barnett and Christina Boyd) has explored how Chevron affects judicial decision-making. ${ }^{26}$ Framing the question by explaining that "a chief and express objective of Chevron deference is to remove politics from judicial decisionmaking," 27 they ask whether "Chevron deference achieve[s] this goal of removing politics from judicial decisionmaking?" 28 They find that, empirically speaking, "the Chevron Court's objective to reduce partisanship in judicial decisionmaking has been quite effective." ${ }^{29}$ By instructing judges to defer to the political judgments (or just statutory interpretations) of agencies, judges are less political in their own decision-making.

21. Motor Vehicle Mfrs. Ass'n of the United States, Inc. v. State Farm Mut. Auto. Ins. Co., 463 U.S. 29 (1983) (defining the modern approach to arbitrary and capriciousness review).

22. Auer v. Robbins, 519 U.S. 452 (1997) (extending Chevron deference to agency interpretations of their own regulations); Bowles v. Seminole Rock \& Sand Co., 325 U.S. 410 (1945) (the precursor to Auer).

23. City of Arlington v. F.C.C., 569 U.S. 290 (2013) (extending Chevron and deference to agency interpretations of their own jurisdiction).

24. Nat'l Cable \& Telecomms. Ass'n v. Brand X Internet Servs., 545 U.S. 967 (2005) (allowing agency interpretations of ambiguous statutes to supersede judicial interpretation of the same statute).

25. F.C.C. v. Fox Television Stations, Inc., 556 U.S. 502 (2009) (holding that an agency's prior interpretation of a statute does not preclude, or impose a heighted burden on, the agency subsequently adopting a contradictory interpretation of the same statute).

26. Barnett, Boyd, \& Walker, supra note 16.

27. Id. at 1466.

28. Walker, Deference Dilemma, supra note 14.

29. Barnett, Boyd, \& Walker, supra note 16, at 1524. 
Hamburger responds to this finding somewhat dismissively: "of course, judges disagree less when the Supreme Court bars them from exercising their independent judgment about what the law is." 30 While a fair critique-indeed, the finding is almost tautological-I would temper it by arguing that it is nonetheless an important empirical finding. Empirics that confirm important theory are as important as empirics that refute it and are too often dismissed.

Rather than focus on concerns about politicized decision-making by judges, Hamburger focuses instead on the importance of judicial independence - on it being "emphatically the duty of the Judicial Department to say what the law is." ${ }^{11} \mathrm{He}$ reframes Walker's results, arguing that "deference" to agencies is really "bias" in favor of the Executive. ${ }^{32} \mathrm{He}$ argues that "Rather than reveal diminished politicization, Walker's numbers provide strong evidence of diminished judicial independence and even of institutionalized judicial bias." 33

So, which is it? Does Chevron reduce bias by de-politicizing judicial decision-making? Or, does it introduce new bias in favor of the (inherently political) Executive? The answer is probably that it does both. The more important answer, however, is that neither is the right question to ask.

\section{The Measure of Politicization}

Walker frames his study of the effects of Chevron on judicial decision-making by explaining that "Chevron deference strives to remove politics from judicial decision-making. Such deference to the political branches has long been a bedrock principle for at least some judicial conservatives." 34 Based on this understanding, his project is to ask whether "Chevron deference achieve[s] this goal of removing politics from judicial decisionmaking?"35

This framing, that one of Chevron's goals is to remove politics from judicial decision-making, is not wrong: One of the Court's justifications for the doctrine offered in Chevron itself was that "Judges are not experts in the field, and are not part of either political branch of the Government." 36 And this reflects the common sentiment that the

30. See Hamburger, Chevron Bias, Illustrated by Statistics, supra note 15.

31. Id. (quoting Marbury v. Madison, 5 U.S. (1 Cranch) 137, 177 (1803) ("It is emphatically the province and duty of the judicial department to say what the law is.") (omission in Hamburger)).

32. See id.

33. Id.

34. Walker, Deference Dilemma, supra note 14.

35. Id.

36. Chevron, U.S.A., Inc. v. Nat. Res. Def. Council, Inc., 467 U.S. 837, 865 (1984). 
Judiciary is separate from the political process and should defer back to the political branches on political questions. But we can think of this goal in another way: It can also be understood as being about preventing the Judiciary from encroaching upon the political purposes assigned to the Executive and Legislative Branches. This reframing is subtle but offers an important change in focus. Instead of being about keeping politics out of judicial decision-making, it emphasizes preventing judicial decision-making out of politics. It emphasizes the concern about politicizing judicial decision-making as a separation of powers issue-and, in particular, it frames Chevron as being, at least in part, about the "duty of the Court to resist the "hydraulic pressures inherent within each of the separate Branches to exceed the outer limits of its power." "37

Under the more common understanding, judges should defer political questions back to the political branches in order to ensure that political decision makers are accountable to the polity they represent. It is of course true that, as unelected officials with lifetime appointments, judges are the least politically accountable of any government officials. Judges' decisions, therefore, can reasonably be expected to be less representative of, or responsive to, the concerns of the voting public than decisions of other government officials. But not all political decisions need to be directly politically accountable in order to be effectively politically accountable. A judicial interpretation of an ambiguous law, for instance, can be interpreted as a request, or even a demand, that Congress be held to political account. And where Congress is failing to perform its constitutionally-defined role as a politically-accountable decision maker, it may do less harm to the separation of powers for the Judiciary to make political decisions that force politically-accountable responses by Congress than for the Judiciary to respect its constitutional role while Congress ignores its role.

Before going too far down this road, I should pause to label the reframing of the debate that I have impliedly proposed. To my mind, the important question is not whether Chevron reduces political decision-making by judges; the question is how Chevron affects the politicization of, and ultimately accountability to the people for, the law. Critically, there is no "conservation of politicization" principle. ${ }^{38}$

37. Louis Fisher, Separation of Powers: Interpretation Outside the Courts, 18 PEPP. L. Rev. 57, 59 (1990) (quoting INS v. Chadha, 462 U.S. 919, 951 (1983)).

38. See, e.g., Daron Acemoglu, Why Not a Political Coase Theorem? Social Conflict, Commitment, and Politics, 31 J. Comp. Econ. 620 (2003); Jean-Jacques Laffont \& David Martimort, Transaction Costs, Institutional Design and the Separation of Powers, 42 Eur. Econ. Rev. 673 (1998). 
Institutional design matters. ${ }^{39}$ One could imagine a model of government where Congress exercises very direct oversight over what the law is and how it is implemented, with frequent elections and a constitutional prohibition on all but the most express and limited forms of delegation. One can also imagine a more complicated form of government in which responsibilities for making law, executing law, and interpreting law are spread across multiple branches (possibly including myriad agencies governed by rules that even many members of those agencies do not understand). And one can reasonably expect greater politicization of decisions in the latter compared to the former because there are more opportunities for saying that the responsibility for any decision lies with someone else (and therefore for politicization) in the latter than in the "the buck stops here" model of the former. ${ }^{40}$

In the common law tradition, judges exercised an important degree of independence because their job was, necessarily and largely, to "say what the law is." For better or worse, we no longer live in a world where judges are expected to routinely exercise that level of discretion and to therefore have that level of independence. Nor do I believe that "independence" is necessarily or inherently a criterion for the Judiciary, at least in principle. I therefore somewhat disagree with Hamburger's assertion that Chevron necessarily amounts to a problematic diminution in judicial independence.

On a consequentialist understanding of the purposes of judicial independence, we should consider the need for it in terms of whether "independent" judicial decision-making tends to lead to better or worse social outcomes. And here I do find myself sympathetic to Hamburger's concerns about judicial independence. The Judiciary is intended to serve as a check on the other branches. Hamburger's concern about judicial independence is driven by an overwhelmingly correct intuition that the structure envisioned by the Constitution is one in which the independence of judges is an important check on the other branches. With respect to the Congress, this means, in part, ensuring that Congress is held to political account when it does legislative tasks poorly or fails to do them at all.

The courts abdicate this role when they allow agencies to save poorly-drafted statutes through an interpretation of ambiguity.

39. See generally Acemoglu, supra note 38; Laffont \& Martimort, supra note 38.

40. See infra notes $49-51$. 


\section{The Institutional Design of Politicization}

Hamburger tells us that "Judges (and academics) need to wrestle with the realities of how Chevron bias and other administrative power is rapidly delegitimizing our government and creating a profound alienation." ${ }^{41}$ Huzzah! Amen!

Hamburger's approach to these issues is, in very broad descriptive contour, structural and constitutional. He focuses in part on understandings of legislative delegations of power to executive and administrative agencies in English law and on how concern about such delegations affected the framers' structuring of American government in the Constitution. ${ }^{42}$ In effect, he argues that the framers understood the British administrative state as a tool of and as contributing to the tyranny of King George, and the framers placed the legislative power squarely within the ambit of the other branches of government precisely to avoid the tendencies of executive and administrative states towards tyranny. ${ }^{43}$ Translating these concerns to the modern setting, he speaks of Chevron as a bias ("Chevron bias") adopted by the Judiciary in favor of government positions in litigation, and he argues that such a bias in favor of the government (and therefore against citizenplaintiffs) violates basic understandings of due process. ${ }^{44}$ This is problematic on its own, and it is further problematic as an abdication of Article III judges' constitutional positions as independent decision makers.

The formal (and formalist) response to Hamburger's critique is that legislatures necessarily must delegate some legislative authority to the Executive and her officers (and therefore agencies), including discretion in how to interpret and apply that authority. The existence of an administrative state is therefore not only not an anomaly but a necessity. ${ }^{45}$ Under this model, so long as the authority exercised by that state derives in the first instance from the Legislature-and so long as there is recourse for the courts to ensure that that authority does not violate constitutionally-protected rights (no matter how fictional such recourse may $\left.b^{46}\right)$ - the administrative state fits within the constitu-

41. See Hamburger, Chevron Bias, Illustrated by Statistics, supra note 15.

42. See generally Adrian Vermeule, No, 93 Tex. L. Rev. 1547 (2015) (reviewing Hamburger,

Is Administrative Law UnLawful?, supra note 10).

43. $I d$.

44. See generally Hamburger, Chevron Bias, supra note 8.

45. See generally Vermeule, supra note 42.

46. Justin Gus Hurwitz, Meet the Hero Who Fought the Administrative State and Won, HiLL (June 12, 2018, 6:30 PM) (discussing the efforts of the owner of a small medical testing lab who successfully challenged an FTC enforcement action and how those efforts took nearly a decade and put the lab out of business). 
tional design. ${ }^{47}$ Indeed, under this model, because the Legislature has deliberately delegated authority to the Executive, judicial interference in how the Executive exercises that authority would be an unconstitutional encroachment by the Judiciary upon both the Legislative and Executive Branches. In this understanding, Chevron is not a bias in favor of the government, but respect for and refusal to encroach upon the other branches.

My own normative priors leave me generally inclined towards Hamburger's history and his analysis, but as a matter of formal logic, the response is equally compelling. My own approach to these issues, however-which gets us to the same place as Hamburger's-is consequentialist and focuses on the merits of competing institutional designs. The basic critique of the formalist response is that it assumes that legislative and judicial review processes have zero transaction costs (or, at least, transaction costs that are exceptionally low). This leads to two undesirable pathologies of the administrative state. First, it leads to an accumulation of power in the Executive Branch-this is one of the chief concerns taken up by critics of the administrative state, including Hamburger. ${ }^{48}$ Second, and what is actually a more pernicious pathology, it leads to an abdication of responsibility by the legislative branch because jockeying for control of the Executive becomes a less transaction-costly way of shaping policy than the legislative process itself. Indeed, the formalist institutional design encourages an increased politicization of the legislative process.

This pathology is captured by what I call Chevron Step Three. At Step Three of the Chevron analysis, Congress corrects any mistakes made by the Executive or its agencies in implementation of the law or made by the courts in their review of that implementation. The subtle thing about Step Three is that it doesn't exist-Congress is under no obligation to correct problematic interpretations of the laws that it passes, and knowing this, Congress rarely bothers with the politically costly and practically difficult process of clarifying legislation. The first implication of this result, that Congress is less likely to correct agencies' problematic use of delegated authority when that use is backed by deference regimes, is well studied. ${ }^{49}$ But there is a deeper question that comes from Congressional inattention to agency statutory interpretation: What are legislators, freed from the cumbersome task of managing the course of the administrative state, doing with their time?

47. Vermeule, supra note 42 , at 1558.

48. See, e.g., Hamburger, Is Administrative Law Unlawful?, supra note 10.

49. See Bressman, supra note 3, at 570; McCubbins \& Schwartz, supra note 5, at 165-66. 
Due to the illusory nature of Step Three, Chevron encourages the Legislature expressly not to legislate. The more expedient approach for a legislator who disagrees with a Chevron-backed agency action is to campaign on the disagreement-that is, to politicize it. ${ }^{50}$ If the Environmental Protection Agency (EPA) interprets the Clean Air Act too broadly, a legislator argues that we need to retake the White House to get a new administrator in the agency so they can straighten out the EPA's interpretation of the law. If the Federal Communications Commission (FCC) interprets the Communications Act too narrowly, a legislator argues that we need to retake the White House to change the chair so that we can straighten out that mess. And legislators on the other side of these issues argue that we need to keep the White House so that we can protect these right-thinking agency interpretations from reversal by the loons on the other side that want to throw out all of our accomplishments. The campaign slogans write themselves.

So long as laws are written broadly, implementation of those laws turns on the Executive, not on Congress; therefore, political attention is focused on the Executive. ${ }^{51}$ Taking a further step back, so long as Congress can write laws broadly, it has the incentive to do so. Such laws are a political "double-whammy" for legislators. In passing the law, legislators on both sides of an issue can claim a political victory in having solved a problem-few will point out the minutiae that the law has only delegated the problem to an agency to be fixed. And subsequently, however the agency implements the law, legislators will be able to either claim (and campaign on) the agency's success or decry (and campaign on) its failure. ${ }^{52}$

So long as most agencies' governing statutes are broad enough that those agencies can keep the ship of state afloat, even if drifting rudderless, legislators have little incentive to turn inward to engage in the business of government with their legislative peers. Rather, they are freed to turn outward towards their next campaign, vilifying or deifying the administrative decisions of the current government as best suits their electoral prospects.

\section{Politicization and the Deference Domain}

The discussion above is built upon two important premises that bear consideration. The first is a belief in democratic accountability and the

50. See Bressman, supra note 3 , at 571-72.

51. Id. at 569 .

52. Id. at 571-72. 
idea that uncertain policy decisions should ultimately be resolved by the will of the people. Policy decisions, therefore, should generally be made by politically accountable actors within the government. Indeed, the greater a policy decision's political valence, the greater the need for that decision to be made by politically accountable actors.

In principle, in a world with zero transaction costs, the institutional design of government would not matter. ${ }^{53}$ If an agency misinterpreted Congressional instructions, Congress would act as a seamless check on that misinterpretation; and the same for judicial misinterpretation. And voters would seamlessly elect-or impeach-their legislators to ensure that Congress was faithful to their will. In such a world, the choice of deference rules would not matter because all decisions would ultimately be resolved without cost through the political process.

But in a world of positive-and relatively high-transaction costs, the key question becomes what governmental design yields policies closest to those desired by the polity. ${ }^{54}$ As described above, in a transaction-costly system, individual legislators have incentives to transfer politically difficult decisions to the Executive. This shields them from political accountability, allowing them to take credit for having done something and to campaign on the Executive's use of that authority (no matter how the Executive uses it). Deference rules can either encourage or check this behavior. Broad deference rules, such as we have today, encourage broad delegations of ambiguous authority to the Executive and focus voter attention on how the Executive uses that authority. ${ }^{55}$ This exacerbates the impact of the system's transaction costs. Alternatively, less deferential rules act as a check on any Congressional abdication of legislative responsibility, insisting that the more politically accountable branch be primarily responsible for politically valent decisions.

Importantly, this analysis suggests that judicial deference to an agency interpretation of law should be inversely proportional to that law's political valence. Agency actions that go to matters of deep economic or political significance, for instance, ought to receive proportionally less deference. ${ }^{56}$ Congress simultaneously has great incentives to "pass the buck" on these questions but also the most political ac-

53. See Acemoglu, supra note 38, at 621.

54. Id. at 621-22.

55. Aziz Z. Huq, The Negotiated Structural Constitution, 114 Colum. L. Rev. 1595, 1622-23 (2014).

56. See, e.g., discussion of the "major questions doctrine," supra note 12. 
countability in addressing them. Similarly, questions that go to the scope of an agency's jurisdiction are best addressed by Congress.

The second premise that bears consideration is that the deference puzzle described above assumes that a new administration can come in after an election and simply rewrite all of the rules adopted by the previous administration. Not to put too fine a point on the matter, but this is exactly what administrative law allows. ${ }^{57}$ This power isn't formally an aspect of Chevron but derives from the same underlying logic. The basic logic of Chevron is that statutory ambiguity delegates to agencies a "policy space" within which they are free to operate..$^{58}$ Under this logic, there is no reason for a court to say any given interpretation of an ambiguous law is better or worse than another, so long as each interpretation falls within that permissible policy space. And so long as agency action stays within that space-including by changing an interpretation of the law-the courts say that it is up to Congress, not the Judiciary, to provide course corrections. Anything else would amount to politically unaccountable judges substituting their policy judgments (this is, acting independently) for those of politically accountable legislators and administrators.

In effect, the politicization of law seen in our current political moment is largely a function of deference combined with a lack of an administrative concept of stare decisis. A virtue of stare decisis is that it forces Congress to directly address politically undesirable opinions. Because agencies are not bound by stare decisis, an alternative, and politically preferable, way for Congress to remedy problematic agency decisions is to politicize the issue. Instead of addressing the substantive policy issue through legislation, individual members of Congress can campaign on it. To take one recent example, consider the net neutrality Congressional Review Act (CRA) vote prior to the 2018 midterm elections, ${ }^{59}$ which was widely recognized as having very little chance of success but was championed by its proponents as a way to influence the 2018 elections. ${ }^{60}$ This is more directly aligned with an individual Congresswoman's own incentives, because, by keeping and

57. See generally F.C.C. v. Fox Television Stations, Inc., 556 U.S. 502 (2009); Motor Vehicle Mfrs. Ass'n of the United States, Inc. v. State Farm Mut. Auto. Ins. Co., 463 U.S. 29 (1983).

58. See E. Donald Elliott, Chevron Matters: How the Chevron Doctrine Redefined the Roles of Congress, Courts and Agencies in Environmental Law, 16 Vill. EnVTL. L.J. 1, 11-12 (2005); Jacob E. Gersen \& Adrian Vermeule, Chevron as a Voting Rule, 116 YAlE L.J. 676, 691 (2007).

59. Geoffrey Manne \& Kristian Stout, The Net Neutrality CRA May Be the Most Tedious Piece of Political Theater Ever, TRuTh ON MARKet (May 16, 2018), https://truthonthemarket .com/2018/05/16/the-net-neutrality-cra-may-be-the-most-tedious-piece-of-political-theater-ever/.

60. David McCabe, Dems Hope Net Neutrality Will Be Election Issue for Young Voters, Axios (Jan. 9, 2018), https://www.axios.com/dems-say-net-neutrality-will-1515515363-e2bc5236-0a4940ed-9089-6ad10f8b34f6.html. 
placing more members of her party in Congress, her party will be able to control the leadership of the agency which will thus control the shape of that agency's policy. In other words, instead of channeling the attention of individual Congressional actors inwards to work together to develop law and policy, that attention is channeled outwards towards campaigning on the ills and evils of the opposing administration and party vice the virtues of their own party.

The virtue of judicial independence-of judges saying what they think the law is or even what they think the law should be-is that it forces a politically accountable decision. Congress can either agree or disagree, but Congress must do something. Merely waiting for the next administration to come along will not be sufficient to alter the course set by the judicial interpretation of the law. Where Congress has abdicated its responsibility to make politically accountable decisions by deferring those decisions to the Executive or its agencies, the political-accountability justification for Chevron deference fails. In such cases, the better course for the courts may well be to enforce Congress's role under separation of powers by refusing deference and returning the question to Congress.

\section{Conclusion}

The ultimate backstop on poor implementation of the law, by either agencies or courts, is the political process-that is, the will of the people as manifested generally through legislative response to that implementation. Therefore an important, and largely unexplored, question is how the institutional design of the governmental decision-making process - both within each branch and across the branches-attenuates (or amplifies) the responsiveness of the legislative process to the will of the people. ${ }^{61}$ Different institutional designs can either insulate agencies and judges from or expose them to greater political accountability. Deference regimes have a significant effect on this process. Greater deference to agencies' statutory interpretations can encourage legislators to delegate more authority to agencies and to exercise less oversight of how that authority is used. This Essay has argued that by embracing such doctrines, the Judiciary facilitates the Legislature's abdication of its constitutional role-and in so doing, the Judiciary itself arguably abdicates its own constitutional role.

61. See, e.g., Cary Coglianese \& Kristin Firth, Separation of Powers Legitimacy: An Empirical Inquiry into Norms About Executive Power, 164 U. PA. L. REv. 1869, 1872 (2016) (noting that "the empirical effects of structural aspects of constitutional law have so far largely escaped systematic study"). 
Whether and the extent to which this argument is accurate raises empirical and theoretical questions that are important for understanding our contemporary administrative state. It is likely the case, for instance, that the concerns raised here do not apply across the board to all applications of deference. Extending deference to major questions that go to the bounds of an agency's basic jurisdiction or concern great economic or political significance is more likely to damage the separation of powers than extending deference to mundane questions about the meaning of ambiguous statutory terms. But the lines between those categories, and the extent to which deference extended in different contexts may have institutionally deleterious effects, are unclear.

Regardless, we find ourselves in a moment of great concern about both the structure of the administrative state and increased polarization and partisanship across the government. Ongoing work by both critics and supporters of the administrative state is sharpening our understanding of these concerns. This Essay adds a new dimension to concerns about the administrative state, relating the deference principles at the core of our contemporary administrative state to broader concerns about the increased political polarization that has come to characterize our government. If, as hypothesized here, deference doctrines do lead legislators to forego their constitutional role in favor of a more partisan government, it is important for us to understand this result as it relates to the operation of both Congress and the administrative state. 
634

DEPAUL LAW REVIEW

[Vol. 68:615 